\title{
PENJAMINAN MUTU PENILAIAN PENDIDIKAN
}

\author{
Umi Salamah \\ Dosen STAI Ma'had Aly Al-Hikam Malang \\ umisalamah393@gmail.com
}

\begin{abstract}
ABSTRAK
Standar Penilaian Pendidikan adalah kriteria mengenai mekanisme, prosedur, dan instrumen penilaian hasil belajar peserta didik. Standar penilaian oleh pendidik menurut BSNP mencakup standar umum, standar perencanaan, standar pelaksanaan, standar pengolahan dan pelaporan hasil penilaian serta standar pemanfaatan hasil penilaian. Masing-masing standar ini memiliki prinsip-prinsip dan kriteria yang ditetapkan oleh BSNP. Sementara itu, penilaian hasil belajar yang dilakukan oleh satuan pendidikan memiliki dua standar pokok yang harus diperhatikan, yaitu: standar penentuan kenaikan kelas dan standar penentian kelulusan.
\end{abstract}

Kata Kunci: penjaminan mutu, penilaian pendidikan

\section{PEMBAHASAN}

\section{A. Standar Penilaian Pendidikan}

Penilaian pendidikan merupakan proses pengumpulan dan pengolahan informasi untuk mengukur pencapaian hasil belajar peserta didik mencakup: penilaian otentik, penilaian diri, penilaian berbasis portofolio, ulangan, ulangan harian, ulangan tengah semester, ulangan akhir semester, ujian tingkat kompetensi, ujian mutu tingkat kompetensi, ujian nasional, dan ujian sekolah/madrasah.

Dalam Permendikbud Nomor 66 Tahun 2013 tentang Standar Penilaian Pendidikan disebutkan bahwa penilaian hasil belajar peserta didik pada jenjang pendidikan dasar dan menengah didasarkan pada prinsip-prinsip sebagai berikut:

a. Objektif, berarti penilaian berbasis pada standardan tidak dipengaruhi faktor subjektivitas penilai.

b. Terpadu, berarti penilaian oleh pendidik dilakukan secara terencana, menyatu dengan kegiatan pembelajaran, dan berkesinambungan.

c. Ekonomis, berarti penilaian yang efisien dan efektif dalam perencanaan, pelaksanaan, dan pelaporannya.

d. Transparan, berarti prosedur penilaian, kriteria penilaian, dan dasar pengambilan keputusan dapat diakses oleh semua pihak. 
e. Akuntabel, berarti penilaian dapat dipertanggungjawabkan kepada pihak internal sekolah maupun eksternal untuk aspek teknik, prosedur, dan hasilnya.

f. Edukatif, berarti mendidik dan memotivasi peserta didik dan guru.

Jika dibandingkan dengan prinsip-prinsip penilaian hasil belajar di atas dengan prinsip-prinsip umum yang ditetapkan oleh Badan Standar Nasional Pendidikan, maka nampak prinsip-prinsip di atas lebih ringkas dari pada yang ditetapkan oleh BNSP. ${ }^{1}$ Demikian pula secara substansi tidak ditemukan perbedaan yang cukup mencolok antara prinsip penilaian yang ada dalam Permendikbud No. 66 tentang Standar Penilaian Pendidikan dengan yang ditetapkan oleh BNSP.

BSNP juga menegaskan bahwa dalam proses penilaian perlu pula diperhatikan prinsip-prinsip khusus sebagi berikut:

1. Penilaian ditujukan untuk mengukur pencapaian kompetensi.

2. Penilaian menggunakan acuan kriteria, yaitu keputusan yang diambil berdasarkan apa yang seharusnya dapat dilakukan oleh peserta didik setelah mengikuti proses pembelajaran.

3. Penilaian dilakukan secara keseluruhan dan berkelanjutan.

4. Hasil penilaian digunakan untuk menentukan tindak lanjut.

5. Penilaian harus sesuai dengan pengalaman belajar yang ditempuh dengan proses pembelajaran. ${ }^{2}$

\section{B. Standar Penilaian oleh Pendidik}

Standar penilaian oleh pendidik menurut BSNP mencakup standar umum, standar perencanaan, standar pelaksanaan, standar pengolahan dan pelaporan hasil penilaian serta standar pemanfaatan hasil penilaian.

\section{a. Standar Umum Penilaian}

Standar umum penialaian adalah aturan main dari aspek-aspek umum dalam pelaksanaan penilaian. BSNP menjabarkan standar umum penilaian ini ke dalam beberapa prinsip sebagaimana berikut:

1. Pemilihan teknik penilaian disesuaikan dengan karakteristik mata pelajaran serta jenis informasi yang ingin diperoleh dari psereta didik.

2. Informasi yang dihimpun mencakup ranah-ranah yang sesuai dengan standar isi dan standar kompetensi lulusan.

3. Informasi mengenai perkembangan perilaku peserta didik dilakukan secara berkala pada kelompok mata pelajaran masing-masing.

${ }^{1}$ Prinsip-prinsip umum penilaian hasil belajar menurut BSNP adalah sebagai berikut: mendidik; terbuka atau transparan; menyeluruh; terpadu dengan pembelajaran; objektif; sistematis; berkesinambungan; adil; dan pelaksanaannya menggunakan acuan kriteria. hlm. 52-53

${ }^{2}$ Ibid., 
4. Pendidik harus selalu mencatat perilaku peserta didik yang menonjol, baik yang bersifat positif maupun negatif dalam buku catatan perilaku.

5. Melakukan sekurang-kurangnya tiga kali ulangan harian menjelang ulangan tengah semester, dan tiga kali menjelang ulangan akhir semster.

6. Pendidik harus menggunakan teknik penilaian yang bervariasi sesuai dengan kebutuhan.

7. Pendidik harus memeriksa dan memberikan balikan kepada peserta didik atas hasil kerjanya sebelum memberikan tugas lanjutan.

8. Pendiidik harus memeiliki catatan kumulatif tentang hasil penilaian untuk setiap peserta didik yang berada di bawah tanggung jawabnya. Pendidik harus mencatat semua kinerja peserta didik untuk menentukan pencapaian kompetensi peserta didik.

9. Pendidik melakukan ulangan tengah dan akhir semester untuk menilai penguasaan kompetensi sesuai dengan tuntutan dalam standar kompetensi (SK) dan standar lulusan (SL).

10. Pendidik yang diberi tugas menangani pengembangan diri harus melaporkan kegiatan peserta didik kepada wali kelas untuk dicantumkan jenis kegiatan pengembangan diri pada buku laporan pendidikan.

11. Pendidik menjaga kerahasiaan peserta didik dan tidak disampaikan kepada pihak lain tanpa seizin yang bersangkutan maupun orangtua/wali murid.

\section{b. Standar Perencanaan Penilaian}

Kaitannya dengan standar perencanaan penilaian ini, BSNP menetapkan tujuh prinsip sebagai berikut:

1. Pendidik harus membuat rencan penilaian secara terpadu dengan silabus dan rencana pembelajarannya. Perencanaan penilaian setidaktidaknya meliputi komponen yang akan dinilai, teknik yang akan digunakan serta kriteria pencapaian kompetensi.

2. Pendidik harus mengembangkan kriteria pencapaian kompetensi dasar (KD) sebagai dasar untuk penilaian.

3. Pendidik menentukan teknik penilaian dan instrumen penilaiannya sesuai dengan indikator pencapaian KD.

4. Pendidik harus menginformasikan seawal mungkin kepada peserta didik tentang aspek-aspek yang dinilai dan kriteria pencapaiaannya.

5. Pendidik menuangkan seluruh komponen penilaian ke dalam kisi-kisi penilaian.

6. Pendidik membuat instrumen berdasarkan kisi-kisi yang telah dibuat dan dilengkapi dengan pedoman penskoran sesuai dengan teknik penilaian yang digunakan. 
7. Pendidik menggunakan acuan kriteria dalam menentukan nilai peserta didik.

\section{c. Standar Pelaksanaan Penilaian}

BSNP menyebutkan dalam pedoman umum, bahwa standar pelaksanaan penilaian yang dilakukan pendidik meliputi:

1. Pendidik melakukan kegiatan penilaian sesuai dengan rencana penilaian yang telah disusun di awal kegiatan pembelajaran.

2. Pendidik menganalisis kualitas instrumen dengan mengacu pada persyaratan instrumen serta menggunakan acuan kriteria.

3. Pendidik menjamin pelaksanaan ulangan dan ujian yang bebas dari kemungkinan terjadinya tindak kecurangan.

4. Pendidik memeriksa pekerjaan peserta didik dan memberikan umpan balik dan komentar yang bersifat mendidik.

\section{d. Standar Pengolahan dan Pelaporan Hasil Penilaian}

Dalam hal standar pengolahan dan pelaporan hasil penilaian BNSP ditetapkan beberapa kriteria yang meliputi:

1. Pemberian skor untuk setiap komponen yang dinilai.

2. Penggabungan skor yang diperoleh dari berbagai teknik dengan bobot tertentu sesuai dengan aturan yang telah ditetapkan.

3. Penentuan satu nilai dalam bentuk angka untuk setiap mata pelajaran, serta menyampaikan kepada wali kelas untuk ditulis dalam buku laporan pendidikan masing-masing peserta didik.

4. Pendidik menulis deskriptif naratif tentang akhlak mulia, kepribadian dan potensi peserta didik yang disampaikan kepada wali kelas.

5. Pendidik bersama wali kelas menyampaikan hasil penilaiannya dalam rapat dewan guru untuk menentukan kenaikan kelas.

6. Pendidik bersama wali kelas menyampaikan hasil penilaiannya kepada dewan guru untuk menentukan kelulusan peserta didik pada akhir satuan pendidikan dengan mengacu pada persyaratan kelulusan satuan pendidikan.

7. Pendidik bersama wali kelas menyampaikan hasil penilaiannya kepada orang tua/wali peserta didik

\section{e. Standar Pemanfaatan Hasil Penilaian}

BSNP menentukan lima standar pemanfaatan hasil penilaian sebagai berikut:

1. Pendidik mengklasifikasikan peserta didik berdasar tingkat ketuntasan pencapaian Standar Kompetensi (SK) dan kompetensi dasar (KD).

2. Pendidik menyampaikan balikan kepada peserta didik tentang tingkat capaian hasil belajar pada setiap KD disertai dengan rekomendasi tindak lanjut yang harus dilakukan. 
3. Bagi peserta didik yang belum mencapai standar ketuntasan, pendidik harus melakukan pembelajaran remidial agar setiap peserta didik dapat mencapai standar ketuntasan yang dipersyaratkan.

4. Kepada peserta didik yang telah mencapai standar ketuntatasan yang dipersyaratkan dan dianggap memiliki keunggulan, pendidik dapat memberikan layanan pengayaan.

5. Pendidik menggunakan hasil penilaian untuk mengevaluasi efektifitas kegiatan pembelajaran dan merencanakan berbagai upaya tindak lanjut.

\section{Standar Penilaian oleh Satuan Pendidikan}

Seperti yang tertuang dalam pasal 63 PP. No. 19/2005 tentang Standar Nasional Pendidikan, baik itu pendidikan dasar dan menengah atau perguruan tinggi, penilaian hasil belajar tidak hanya dilakukan oleh pendidik saja, melainkan juga dilakukan oleh satuan pendidikan. Menurut BSNP, terdapat dua standar pokok yang harus diperhatikan dalam penilaian hasil belajar oleh satuan pendidikan, yaitu:

a. Standar penentuan kenaikan kelas, yang terdiri atas tiga hal pokok, yaitu:

1) Pada akhir tahun pelajaran, satuan pendidikan menyelenggarakan ujian kenaikan kelas.

2) Satuan pendidikan menentukan Standar Ketuntasan Belajar Minimal (SKBM) pada setiap mata pelajaran. SKBM tersebut harus ditingkatkan secara berencana dan berkala.

3) Satuan pendidikan menyelenggarakan rapat Dewan pendidikan untuk menentukan kenaikan kelas setiap peserta didik.

b. Standar penentuan kelulusan

1) Pada akhir jenjang pendidikan, satuan pendidikan menyelenggarakan ujian sekolah pada kelompok mata pelajaran IPTEKS.

2) Satuan pendidikan menyelenggarakan rapat dewan pendidikan untuk menentukan nilai akhir peserta didik pada: a)Kelompok mata pelajaran agama dan akhlak mulia; b) Kelompok mata pelajaran kewarganegaraan dan kepribadian; c) Kelompok mata pelajaran estetika, dan d) Kelompok mata pelajaran jasmani, olah raga dan kesehatan untuk menentukan kelulusan.

3) Satuan pendidikan menentukan kelulusan peserta didik berdasarkan kriteria kelulusan yang ditetapkan dalam Peraturan Pemerintah No. 10/2005 pasal 72 ayat (1) yang menyaakan bahwa peserta didik dinyatakan lulus dari satuan pendidikan pada pendidikan dasar dan menengah setelah: a) Menyelesaikan seluruh program pembelajaran,b) Memperoleh nilai minimal baik pada penilaian akhir untuk mata pelajaran kelompok mata 
pelajaran agama dam akhlak mulia, kelompok mata pelajaran kewarganegaraan dan kepribadian, kelompok mata pelajaran estetika, dan kelompok mata pelajaran jasmani, olah raga dan kesehatan, c) Lulus ujian sekolah/madrasah untuk kelompok mata pelajaran ilmu pengetahuan dan teknologi; dan d)Lulus ujian nasional.

\section{A. Standar Penilaian Pendidikan pada KTSP}

\section{Penilaian Berbasis Kelas}

Penilaian Berbasis Kelas (PBK) adalah penilaian yang dilakukan oleh guru dalam rangka proses pembelajaran. PBK merupakan proses pengumpulan dan penggunaan informasi hasil belajar peserta didik yang dilakukan oleh guru untuk menetapkan tingkat pencapaian dan penguasaan peserta didik terhadap tujuan pendidikan (standar komptensi, komptensi dasar, dan indikator pencapaian hasil belajar). Penilaian berbasis kelas, dilakukan baik dalam bentuk tes tertulis, kinerja/penampilan, penugasan (project), hasil karya (product), maupun pengumpulan kerja siswa (portofolio). Dalam praktiknya penilaian PBK harus memperhatikan tiga ranah kognitif, afektif dan psikomotorik. ${ }^{3}$

2. Penialaian Kinerja (Performance)

Penilian kinerja adalah penilaian berdasarkan hasil pengamatan penilaian terhadap aktivitas siswa sebagaimana yang terjadi. Penilaian kinerja biasanya digunakan untuk menilaian kemampuan siswa dalam berpidato, pembacaan puisi, diskusi, pemecahan masalah, partisipasi siswa dalam berdiskusi, memainkan alat music, olahraga dan lain-lain ${ }^{4}$

\section{Penilaian Penugasan (Proyek)}

Penilaian penugasan proyek merupakan penilaian untuk mendapatkan gambaran kemampuan menyeluruh/umum secara konstektual, mengenai kemampuan siswa dalam menerapkan konsep dan pemahaman mata pelajaran tertentu. 5

\section{Penilaian Hasil Kerja (Produk)}

Penilaian hasil kerja atau produk merupakan penilaian kepada siswa dalam mengontrol proses dan memanfaatkan/menggunakan bahan untuk menghasilkan

\footnotetext{
${ }^{3}$ Masnur Muslich, KTSP Pembelajaran Berbasis Kompetensi dan Kontektual,
} Panduan Bagi Guru, Kepala Sekolah, dan Pengawas Sekolah, (Jakarta: Bumi Aksara, 2007), hlm 91.

${ }^{4}$ Ibid, hlm. 95-96.

$5 \mathrm{lbid}, \mathrm{hlm} .105$. 
sesuatu,kerja praktik atau kualitas estetis dari sesuatu yang mereka produksi. $^{6}$

\section{Penilaian Tes tertulis}

Penilaian secara tertulis dilakukan dengan cara tertulis. Tes tertulis merupakan tes dimana soal dan jawabannya yang diberikan kepada peserta didik dalam bentuk tertulis. ${ }^{7}$

\section{Penilaian Portofolio}

Portofolio merupakan kumpulan hasil kerja siswa/suatu koleksi pribadi hasil pekerjaan seseorang siswa (bersifat individual) yang menggambarkan (merefleksikan) taraf pencapaian, kegiatan belajar, kekuatan, dan pekerjaan terbaik siswa. Hasil kerja tersebut sering disebut artefak. Artefak-artefak dihasilkan dari pengalaman belajar/proses pembelajaran siswa dalam periode tertentu. ${ }^{8}$

\section{Penilaian Sikap}

Penilaian sikap merupakan penilaian terhadap perilaku dan keyakinan siswa terhadap suatu obyek, fenomena/masalah. Secara umum, penilaian sikap dalam berbagai mata pelajaran dapat dilakukan berkaitan dengan berbagai obyek sikap sebagai berikut : a) Sikap terhadap mata pelajaran, b) Sikap guru terhadap mata pelajaran, c) Sikap terhadap proses pembelajaran, dan lain-lain.

Penilaian ini dapat dilakukan dengan beberapa cara, antara lain:

1. Observasi perilaku, misalnya tentang kerja sama, inisiatif, perhatian.

2. Pertanyaan langsung, misalnya tanggapan terhadap tata tertib sekolah yang baru

3. Laporan pribadi, misalnya menulis tentang "Indahnya kebersamaan"

\section{Penilaian Diri (Self Assessment)}

Penilaian diri di tingkat kelas atau Classroom Self Assessment (CSA) adalah penilaian yang dilakukan sendiri oleh guru atau siswa yang bersangkutan untuk kepentingan pengelolaan kegiatan belajar mengajar (KBM) di tingkat kelas.

\footnotetext{
${ }^{6}$ Ibid, hlm. 115.

${ }^{7}$ Ibid, hlm. 117.

${ }^{8}$ Ibid, hlm. 118.
} 


\section{B. Standar Penilaian Pendidikan pada Kurikulum 2013}

Istilah autentik merupakan sinonim dari asli, nyata, valid, atau variable. Jadi penilaian autentik adalah proses pengumpulan informasi tentang perkembangan dan pencapaian pembelajaran yang dilakukan oleh peserta didik melalui berbagai teknik yang mampu mengungkapkan, membuktikan atau menunjukkan secara tepat bahwa tujuan pembelajaran telah benar-benar dikuasai dan dicapai. Berdasarkan lampiran Permendikbud Nomor 66 Tahun 2013 tantang Standar Penilaian yang dilakukan secara komperhensif untuk menilai, mulai dari proses hingga keluar (output) pembelajaran. Penilaian autentik mencakup ranah sikap, keterampilan, dan pengetahuan. ${ }^{9}$

\section{Macam-macam Penilaian}

Standar Penilaian Pendidikan adalah kriteria mengenai mekanisme, prosedur, dan instrumen penilaian hasil belajar peserta didik. $^{10}$

Penilaian dalam kurikulum 2013 mengacu pada Permendikbud Nomor 66 Tahun 2013 tentang Standar Penilaian Pendidikan. Standar penilaian bertujuan untuk menjamin (1) perencanaan penilaian pserta didik sesuai dengan kompetensi yang akan dicapai dan berdasarkan prinsip-prinsip penilaian, (2) pelaksanaan penilaian peserta didik secara professional, terbuka, edukatif, efektif, efisien, dan sesuai dengan konteks social budaya, (3) pelaporan hasil penilaian peserta didik secara objektif, akuntabel, dan inofatif. ${ }^{11}$

Penilaian pendidikan sebagai proses pengumpulan dan pengolahan informasi untuk mengukur pencapaian hasil belajar peserta didik mencakup: penilaian otentik, penilaian diri, penilaian berbasis portofolio, ulangan, ulangan harian, ulangan tengah semester, ulangan akhir semester, ujian tingkat kompetensi, ujian mutu tingkat kompetensi, ujian nasional, dan ujian sekolah/madrasah, yang diuraikan sebagai berikut.

9 Munardi dan Selly Rahmawati, Penilaian dalam Kurikulum 2013: Membantu Guru dan Calon Guru Mengetahui Langkah-langkah Penilaian Pembelajaran, (Jogjakarta: Andi, 2013), hlm. 27.

10 Permendikbud Nomor 66 Tahun 2013 tentang Standar Penilaian Pendidikan, hlm. 2.

${ }^{11}$ Kunandar, Penilaian Autentik: Penilaian Hasil Belajar Peserta Didik Berdasarkan Kurikulum 2013, (Jakarta: Raja Grafindo Persada, 2013), hlm. 35 
a. Penilaian Otentik

Penilaian otentik merupakan penilaian yang dilakukan secara komprehensif untuk menilai mulai dari masukan (input), proses, dan keluaran (output) pembelajaran. ${ }^{12}$

b. Penilaian Diri

Penilaian diri merupakan penilaian yang dilakukan sendiri oleh peserta didik secara reflektif untuk membandingkan posisi relatifnya dengan kriteria yang telah ditetapkan.

c. Penilain Berbasis Portofolio

Penilaian berbasis portofolio merupakan penilaian yang dilaksanakan untuk menilai keseluruhan entitas proses belajar peserta didik termasuk penugasan perseorangan dan/atau kelompok di dalam dan/atau di luar kelas khususnya pada sikap/perilaku dan keterampilan.

d. Ulangan

Ulangan merupakan proses yang dilakukan untuk mengukur pencapaian kompetensi peserta didik secara berkelanjutan dalam proses pembelajaran, untuk memantau kemajuan dan perbaikan hasil belajar peserta didik.

e. Ulangan Harian

Ulangan harian merupakan kegiatan yang dilakukan secara periodic untuk menilai kompetensi peserta didik setelah menyelesaikan satu Kompetensi Dasar (KD) atau lebih.

f. Ulangan Tengah Semester

Ulangan tengah semester merupakan kegiatan yang dilakukan oleh pendidik untuk mengukur pencapaian kompetensi peserta didik setelah melaksanakan 8 - 9 minggu kegiatan pembelajaran. Cakupan ulangan tengah semester meliputi seluruh indikator yang merepresentasikan seluruh KD pada periode tersebut.

g. Ulangan Akhir Semester

Ulangan akhir semester merupakan kegiatan yang dilakukan oleh pendidik untuk mengukur pencapaian kompetensi peserta didik di akhir semester. Cakupan ulangan meliputi seluruh indikator yang merepresentasikan semua KD pada semester tersebut. ${ }^{13}$

12 Permendikbud Nomor 66 Tahun 2013 tentang Standar Penilaian Pendidikan, hlm. 2.

13 Permendikbud Nomor 66 Tahun 2013 tentang Standar Penilaian Pendidikan, hlm. 2. 


\section{h. Ulangan Tingkat Kompetensi}

Ujian Tingkat Kompetensi yang selanjutnya disebut UTK merupakan kegiatan pengukuran yang dilakukan oleh satuan pendidikan untuk mengetahui pencapaian tingkat kompetensi. Cakupan UTK meliputi sejumlah Kompetensi Dasar yang merepresentasikan Kompetensi Inti pada tingkat kompetensi tersebut.

i. Ujian Mutu Pendidikan Kompetensi

Ujian Mutu Tingkat Kompetensi yang selanjutnya disebut UMTK merupakan kegiatan pengukuran yang dilakukan oleh pemerintah untuk mengetahui pencapaian tingkat kompetensi. Cakupan UMTK meliputi sejumlah Kompetensi Dasar yang merepresentasikan Kompetensi Inti pada tingkat kompetensi tersebut.

\section{j. Ujian Nasional}

Ujian Nasional yang selanjutnya disebut UN merupakan kegiatan pengukuran kompetensi tertentu yang dicapai peserta didik dalam rangka menilai pencapaian Standar Nasional Pendidikan, yang dilaksanakan secara nasional.

\section{k. Ujian Sekolah/Madrasah}

Ujian Sekolah/Madrasah merupakan kegiatan pengukuran pencapaian kompetensi di luar kompetensi yang diujikan pada UN, dilakukan oleh satuan pendidikan. ${ }^{14}$

\section{Teknik Penilaian ${ }^{15}$}

Penilaian dilakukan dalam berbagai teknik untuk semua kompetensi dasar yang dikategorikan dalam tiga aspek, yaitu sikap, pengetahuan, dan keterampilan.

\section{a. Sikap}

Penilaian aspek sikap dilakukan melalui observasi, penilaian diri, penilaian antarteman, jurnal selama proses pembelajaran berlangsung, dan tidak hanya di dalam kelas.

1) Observasi

Merupakan teknik penilaian yang dilakukan secara berkesinambungan dengan menggunakan indera, baik secara langsung maupun tidak langsung dengan menggunakan format observasi yang berisi sejumlah

14 Permendikbud Nomor 66 Tahun 2013 tentang Standar Penilaian Pendidikan, hlm. 2.

${ }^{15}$ Kementrian Pendidikan dan Kebudayaan, Panduan Teknis Penilaian dan Pengisian Rapot di SD, (Jakarta: Direktorat Jenderal Pendidikan Dasar, 2014), hlm. 17. 
indikator perilaku yang diamati. Hal ini dilakukan saat pembelajaran maupun di luar pembelajaran.

2) Penilaian Diri

Penilaian Diri adalah teknik penilaian sikap, pengetahuan, dan keterampilan yang dilakukan sendiri sebelum ulangan oleh peserta didik secara reflektif. Penilaian diri merupakan teknik penilaian dengan cara meminta peserta didik untuk mengemukakan kelebihan dan kekurangan dirinya dalam konteks pencapaian kompetensi. Instrumen yang digunakan berupa lembar penilaian diri. ${ }^{16}$

3) Penilaian Antarteman

Merupakan teknik penilaian dengan cara meminta peserta didik untuk saling menilai terkait dengan sikap dan perilaku keseharian peserta didik. Instrumen yang digunakan berupa lembar penilaian antarpeserta didik. Penilaian ini dilakukan secara berkala setelah proses pembelajaran. ${ }^{17}$

4) Jurnal Catatan Guru /Jurnal Pendidik

Jurnal Pendidik adalah instrumen penilaian yang digunakan untuk menghimpun catatan pendidik di dalam dan di luar kelas yang berisi informasi hasil pengamatan tentang kekuatan dan kelemahan peserta didik yang berkaitan dengan sikap dan perilaku. Jurnal bisa dikatakan sebagai catatan yang berkesinambungan dari hasil observasi. $^{18}$

\section{b. Pengetahuan}

1) Tes Tulis

Tes tulis adalah tes yang soal dan jawabannya tertulis berupa pilihan ganda, isian, benar-salah, menjodohkan, dan uraian.

2) Tes Lisan

Tes lisan berupa pertanyaan-pertanyaan yang diberikan guru secara lisan dan peserta didik merespon pertanyaan tersebut secara lisan juga, sehingga menumbuhkan sikap berani berpendapat. Jawaban dapat berupa kata, frase, kalimat maupun paragraf.

3) Penugasan

${ }^{16}$ Kementrian Pendidikan dan Kebudayaan, Ibid, hlm. 8.

17 Lif Khoiru Ahmadi dan Sofan Amri, Pengembangan dan Model Pembelajaran Tematik Integratif, (Jakarta: Prestasi Pustakaraya, 2014), hlm. 225.

${ }^{18}$ Kementrian Pendidikan dan Kebudayaan, Ibid, hlm. 9. 
Penugasan adalah penilaian yang dilakukan oleh pendidik yang dapat berupa pekerjaan rumah baik secara individu ataupun kelompok sesuai dengan karakteristik tugasnya. ${ }^{19}$

\section{c. Keterampilan}

Aspek keterampilan dapat dinilai dengan cara berikut: ${ }^{20}$

1) Kinerja atau Performance

Merupakan suatu penilaian yang meminta peserta didik untuk melakukan suatu tugas pada situasi yang sesungguhnya yang mengaplikasikan pengetahuan dan keterampilan yang dibutuhkan. Misalnya memainkan alat musik, menggunakan mikroskop, menyanyi, bermain peran, menari, dan sebagainya.

2) Projek

Merupakan kegiatan penilaian terhadap suatu tugas yang harus diselesaikan dalam periode/waktu tertentu. Tugas tersebut berupa suatu investigasi sejak dari perencanaan, pengumpulan data, pengorganisasian, pengolahan dan penyajian data.

Penilaian projek dapat digunakan untuk mengetahui pemahaman, kemampuan mengaplikasikan, kemampuan melakukan penyelidikan dan kemampuan menginformasikan peserta didik pada muatan tertentu secara jelas. Pada penilaian projek setidaknya ada 3 (tiga) hal yang perlu dipertimbangkan yaitu:

a) Kemampuan Pengelolaan

Kemampuan peserta didik dalam memilih topik, mencari informasi dan mengelola waktu pengumpulan data, serta penulisan laporan.

b) Relevansi

Kesesuaian tugas projek dengan muatan mata pelajaran, dengan mempertimbangkan tahap pengetahuan, pemahaman dan keterampilan dalam pembelajaran.

c) Keaslian

Projek yang dilakukan peserta didik harus merupakan hasil karyanya, dengan mempertimbangkan kontribusi guru berupa petunjuk dan dukungan terhadap projek peserta didik. $^{21}$

${ }^{19}$ Sunardi dan Selly Rahmawati, Op, Cit, hlm.42.

${ }^{20}$ Kementrian Pendidikan dan Kebudayaan, Op.Cit, hlm. 10.

21 Kementrian Pendidikan dan Kebudayaan, Op.Cit, hlm.11. 
3) Portofolio

Penilaian portofolio pada dasarnya menilai karya-karya peserta didik secara individu pada satu periode untuk suatu sub tema. Akhir suatu periode hasil karya tersebut dikumpulkan dan dinilai oleh guru dan peserta didik. Berkaitan dengan tujuan penilaian portofolio, tiap item dalam porto folio harus memiliki suatu nilai atau kegunaan bagi peserta didik dan bagi orang yang mengamatinya. Guru dan peserta didik harus sama-sama memahami maksud, mengapa suatu item (artefak) dimasukkan kedalam koleksi portofolio. Selain itu, sangat diperlukan komentar dan refleksi baik dari guru ataupun pengamat tertentu yang memiliki keterkaitan dengan artefak yang dikoleksi. ${ }^{22}$

Berdasarkan informasi perkembangan kemampuan peserta didik yang dibuat oleh guru bersama peserta didik yang bersangkutan, dapat dilakukan perbaikan secara terus menerus. Dengan demikian portofolio dapat memperlihatkan perkembangan kemajuan belajar peserta didik melalui karyanya. Adapun karya peserta didik yang dapat dijadikan dokumen portofolio, antara lain: karangan, puisi, surat, gambar/lukisan, komposisi musik.

Dalam kurikulum 2013, dokumen portofolio dapat dipergunakan sebagai salah satu bahan penilaian untuk aspek keterampilan. Hasil penilaian portofolio bersama dengan penilaian yang lain dipertimbangkan untuk pengisian rapor/laporan penilaian kompetensi peserta didik. Penilaian portofolio merupakan penilaian berkelanjutan yang didasarkan pada kumpulan informasi yang menunjukkan perkembangan kemampuan peserta didik dalam satu periode tertentu. Informasi tersebut dapat berupa karya peserta didik dari proses pembelajaran yang dianggap terbaik oleh peserta didik. ${ }^{23}$

\section{Model Penilaian}

\section{a. Penilaian Aspek Sikap}

Dalam ranah sikap terdapat lima jenjang proses berfikir, yakni (1) menerima dan memperhatikan, (2) merespon/menanggapi,

${ }^{22}$ Masnur Muslich, KTSP Pembelajaran Berbasis Kompetensi dan Kontektual, Panduan Bagi Guru, Kepala Sekolah, dan Pengawas Sekolah, (Jakarta: Bumi Aksara, 2007), hlm 118.

${ }^{23}$ Kementrian Pendidikan dan Kebudayaan, Op.Cit, hlm.11. 
(3) menilai/menghargai, (4) mengorganisasikan/mengelola, (5) berkarakter. $^{24}$

Penilaian sikap dilakukan melalui kegiatan observasi, penilaian diri, penilaian antarteman, dan jurnal.

\section{1) Observasi}

Bentuk instrumen yang digunakan untuk observasi adalah pedoman observasi yang berupa daftar cek atau skala penilaian (rating scale) yang disertai rubrik. Daftar cek digunakan untuk mengamati ada tidaknya suatu sikap atau perilaku. Sedangkan skala penilaian menentukan posisi sikap atau perilaku peserta didik dalam suatu rentangan sikap.

Pedoman observasi secara umum memuat pernyataan sikap atau perilaku yang diamati dan hasil pengamatan sikap atau perilaku sesuai kenyataan. Pernyataan memuat sikap atau perilaku yang positif atau negatif sesuai indikator penjabaran sikap dalam kompetensi inti dan kompetensi dasar. Rentang skala hasil pengamatan antara lain berupa: ${ }^{25}$

a) Selalu, sering, kadang-kadang, tidak pernah

b) Sangat baik, baik, cukup, perlu bimbingan

c) Sangat baik, baik, cukup, perlu bimbingan

Pedoman observasi dilengkapi juga dengan rubrik dan petunjuk penskoran. Rubrik memuat petunjuk/uraian dalam penilaian skala atau daftar cek. Sedangkan petunjuk penskoran memuat cara memberikan skor dan mengolah skor menjadi nilai akhir.

\section{2) Penilaian Diri}

Merupakan teknik penilaian dengan cara meminta peserta didik untuk mengemukakan kelebihan dan kekurangan dirinya dalam konteks pencapaian kompetensi. Instrumen yang digunakan berupa lembar penilaian diri. ${ }^{26}$

\section{3) Penilaian Antarteman}

Merupakan teknik penilaian dengan cara meminta peserta didik untuk saling menilai terhadap sikap dan perilaku keseharian antarteman. Instrumen yang digunakan berupa lembar penilaian antarpeserta didik.Penilaian antarteman

${ }^{24}$ Kunandar, OP. Cit, hlm. 109

${ }^{25}$ Imas Kurinasih dan Berlin Sani, Sukses Mengimplemantasikan Kurikulum 2013: Memahami Berbagai Aspek dalam Kurikulum 2013, (Jakarta: Kata Pena, 2014), hlm. 76.

${ }^{26}$ E. Mulyasa, Pengembangan dan Implementasi Kurikulum 2013, (Bandung: Remaja Rosdakarya, 2013), hlm. 136. 
paling baik dilakukan pada saat peserta didik melakukan kegiatan berkelompok.

\section{4) Jurnal Guru}

Merupakan catatan pendidik di dalam dan di luar kelas yang berisi informasi hasil pengamatan tentang kekuatan dan kelemahan peserta didik yang berkaitan dengan sikap dan perilaku. Jurnal bisa dikatakan sebagai catatan yang berkesinambungan dari hasil observasi. ${ }^{27}$

\section{b. Penilaian Aspek Pengetahuan}

Teknik kompetensi pengetahuan atau kognitif adalah penilaian yang dilakukan guru untuk mengukur tingkat pencapaian atau penugasan peserta didik dalam aspek pengetahuan yang meliputi ingatan/hafalan, pemahaman, penerapan/aplikasi, analisis, sintesis, dan evaluasi. Dalam kurikulum 2013 kompetensi pengetahuan menjadi kompetensi inti dengan kode kompetensi inti 3 (KI 3). Kompetensi pengetahuan merefleksikan konsep-konsep ilmuan yang harus dikuasai oleh peserta didik malalui proses belajar mengajar. ${ }^{28}$

KI 3 yaitu:

Memahami pengetahuan faktual dengan cara mengamati (mendengar, melihat, membaca) dan menanya berdasarkan rasa ingin tahu tentang dirinya, makhluk ciptaan Tuhan dan kegiatannya, dan benda-benda yang dijumpainya di rumah dan di sekolah. ${ }^{29}$

Jenis penilaian dalam aspek pengetahuan dapat berupa:

\section{1) Tes Tertulis}

Ter tertulis yang digunakan guru banyak fariasinya yang mana digunakan untuk mengukur pencapaian kompetensi pengetahuan (kognitif) peserta didik, ter tertulis terdiri dari: soal pilihan ganda, isian, jawaban singkat (pendek), benarsalah, penjodohan, dan uraian. ${ }^{30}$

\section{2) Tes Lisan}

Tes bentuk lisan adalah tes yang dipergunkan mengukur tingkat pencapaian kompetensi, terutama pengetahuan (kognitif) dimana guru memberikan pertanyaan langsung kepada peserta didik secara verbal (lisan) dan ditanggapi

${ }^{27}$ Kementrian Pendidikan dan Kebudayaan, Op.Cit, hlm. 22

${ }^{28}$ Kunandar, Op. Cit, hlm. 165

29 Kementerian Pendidikan dan Kebudayaan, Dokumen Kurikulum 2013, (Jakarta: Kemendikbud, 2013), hlm. 5.

${ }^{30}$ Trianto, Desain Pengembangan Pembelajaran Tematik: Bagi Anak Usia Dini TK/RA dan Anak Usia Awal SD/MI, (Jakarta: Kencana, 2011), hlm. 263. 
peserta didik secara langsung dengan menggunakan bahasa verbal (lisan).

\section{3) Penugasan/Proyek}

Instrument penugasan berupa pekerjaan rumah dan/ proyek yang dikerjakan secara individu atau kelompok sesuai dengan karakteristik tugas. ${ }^{31}$

\section{c. Penilaian Aspek Psikomotorik/Keterampilan}

Dalam ranah keterampilan terdapat lima jenjang proses berpikir, yakni:

1) Imitasi adalah kemampuan melakukan kegiatan-kegiatan sederhana dan sama persis dengan yang lilihat atau diperhatikan sebelumnya. Contoh: seorang peserta didik dapat memukul bola dengan tepat.

2) Manipulasi adalah kemampuan melakukan kegiatan sederhana yang belum pernah dilihat, tetapi berdasarkan pada pedoman atau petunjuk saja.

3) Presisi adalah kemampuan melakukan kegiatan-kegiatan yang akurat sehingga mmapu menghasilakn produk kerja yang tepat.

4) Artikulasi adalah kemampuan melakukan kegiatan yang kompleks dan tepat sehingga hasil kerjanya merupakan sesuatu yang utuh.

5) Naturalisasi adalah kemampuan melakukan kegiatan secara reflek. $^{32}$

Guru menilai kompetensi keterampilan melalui penialaian berupa (1) kinerja, yaitu penilaian yang menuntut peserta didik mendemonstrasikan suatu kompetensi tertentu menggunakan tes praktik (ujuk kerja) dengan menggunakan instrument lembar pengamatan, (2) proyek, dengan menggunakan intrumen lembar penilaian dokumen laporan proyek, (3) penilaian portofolio, dengan menggunakan intrumen lembar penilaian produk dengan menggunakan intrumen lembar penilaian produk. Biasanya guru mengguanakan cek list $(\sqrt{ })$ atau skala penilaian. ${ }^{33}$

\section{1) Penilaian Unjuk Kerja}

2) Portofolio

31 Sholeh Hidayat, Pengembangan Kurikulum Baru, (Bandung: Remaja Rosdakarya, 2013), hlm. 119

${ }^{32}$ Kunandar, Op. Cit, hlm. 259-260.

33 Andi Prastowo, Pengembagan Bahan Ajar Tematik: Panduan Lengkap Aplikatif, (Jogjakarta: Anggota Ikapi, 2013), hlm. 404 
Portofolio adalah kumpulan pekerjaan seseorang yang dalam bidang pendidikan berarti pengumpulan tugas-tugas peserta didik yang memiliki keteraturan dan kebutuha untuk menghasilkan satu kompetensi tertentu. Selanjutnta kumpulan tugas itu dicermati untuk melihat perkembangan kemampuan peserta didik dalam menulis tugas yang diberikan guru. ${ }^{34}$

\section{d. Penjaminan Mutu Penilaian Pendidikan}

Seperti yang tertuang dalam Bab I Pasal 1 ayat (7) UndangUndang Sistem Pendidikan Nasional No. 20 tahun 2003, bahwa "standar nasional pendidikan adalah kriteria minimal tentang sistem pendidikan di seluruh wilayah hukum Negara Kesatuan Republik Indonesia." Artinya, apa yang telah ditetapkan oleh Badan Standar Nasional Pendidikan (BNSP), yang dalam hal ini merupakan sebuah badan yang ditunjuk sebagai kepanjangan atau pewujud dan pelaksana amanat undang-undang tentang standar pendidikan menjadi acuan dasar bagi semua satuan pendidikan yang ada di Indonesia.

Dijelaskan pula bahwa pengembangan standar nasional pendidikan serta pemantauan dan pelaporan pencapaiaannya secara nasional dilaksanakan oleh suatu badan standarisasi, penjaminan, dan pengendalian mutu pendidikan. ${ }^{35}$ Dapat dipahami bahwa salah satu tujuan ditetapkannya standar nasional pendidikan adalah untuk menjamin mutu atau kualitas pendidikan. Dengan standar-standar yang ditentukan dalam setiap komponen yang ada (isi, proses, kompetensi lulusan, tenaga kependidikan, sarana dan prasarana, pengelolaan, pembiayaan, dan penilaian pendidikan) diharapkan mampu meningkatkan atau minimal menjadikan mutu pendidikan di satuan pendidikan yang ada dalam taraf mutu yang layak, mengacu pada kelayakan yang ditentukan pemerintah.

Tilaar memberikan catatan bahwa standar yang ada dalam pendidikan ini bukanlah standar yang kaku, melainkan standar yang terus-menerus meningkat. dengan kata lain kualitas pendidikan nasional semakin lama semakin meningkat. ${ }^{36}$ Misalnya, sebelum dikeluarkannya UU Sisdiknas No. 20 tahun

34 Ibnu Hajar, Panduan lengkap Kurikulum Tematik Untuk SD/MI, (Jogjakarta: Anggota Ikapi, 2013), hlm. 22 dapat juga dilihat pada Martinis Yamin, Paradigma Pendidikan Konstruktivistik: Implementasi KTSP \& UU No. 14 Tahun 2005 tentang Guru dan Dosen, (Jakarta: Anggota Ikapi, 2008), hIm.235.

${ }^{35}$ Zainal Arifin, Op.Cit., hlm. 42

${ }^{36}$ H.A.R. Tilaar, Standarisasi Pendidikan Nasional; Suatu Tinjauan Kritis, (Jakarta: Rineka Cipta, 2006), hlm. 76 
2003 tentang Sistem Pendidikan Nasional. Dunia pendidikan menggunakan landasan Yuridis yaitu Undang-Undang Sistem Pendidikan No. 2 tahun 1989. Dalam UUSPN No. 2 tahun 1989 belum ada rumusan tentang Standar Nasional Pendidikan, sementara dalam UU Sisdiknas No. 20 tahun 2003 telah muncul istilah Standar Nasional Pendidikan.

Dalam undang-undang tersebut, yakni pada Bab XII tentang penilaian, pada Pasal 43 disebutkan: "Terhadap kegiatan dan kemajuan belajar peserta didik dilakukan penilaian." Kemudian dilanjutkan Pasal 44: "Pemerintah dapat menyelenggarakan penilaian hasil belajar suatu jenis dan/atau jenjang pendidikan secara nasional." Kemudian pada Pasal 45 disebutkan: "Secara berkala dan berkelanjutan Pemerintah melakukan penilaian terhadap kurikulum serta sarana dan prasarana pendidikan sesuai dengan kebutuhan dan perkembangan keadaan. " Sedangkan pada Pasal 46, ayat (1): "Dalam rangka pembinaan satuan pendidikan, Pemerintah melakukan penilaian setiap satuan pendidikan secara berkala." (2) Hasil penilaian sebagaimana dimaksud pada ayat (1) diumumkan secara terbuka."

Sementara itu, dalam Undang-Undang Sistem Pendidikan Nasional No. 20 tahun 2003, pada Bab XVI tentang Evaluasi, Akreditasi dan Sertifikasi, Bagian Kesatu: Evaluasi. Pada Pasal 57, ayat (1) disebutkan bahwa: Evaluasi dilakukan dalam rangka pengendalian mutu pendidikan secara nasional sebagai bentuk akuntabilitas penyelenggara pendidikan kepada pihak-pihak yang berkepentingan. Kemudian, pada Pasal 58 ayat (1), ditegaskan juga bahwa: Evaluasi hasil belajar peserta didik dilakukan oleh pendidik untuk memantau proses, kemajuan, dan perbaikan hasil belajar peserta didik secara berkesinambungan, dan pada ayat (2) dinyatakan bahwa: Evaluasi peserta didik, satuan pendidikan, dan program pendidikan dilakukan oleh lembaga mandiri secara berkala, menyeluruh, transparan, dan sistemik untuk menilai pencapaian standar nasional pendidikan.

Dari perbandingan dua Undang-Undang Sistem Pendidikan Nasional terkait dengan penilaian, pada taraf konsepsi, ada kemajuan yang sangat berarti dalam pemaknaan dan fungsi penilaian dalam pendidikan. Jika pada UUSPN No. 2 tahun 1989, diadakannya penilaian dalam pendidikan tidak dikaitkan dengan mutu atau kualitas dari satuan pendidikan. Penilaian pendidikan hanya dilakukan oleh pemerintah. Sementara dalam UU Sisdiknas No. 20 tahun 2003, penilaian pendidikan dikaitkan 
dengan pengendalian mutu suatu satuan pendidikan. Selain itu, penilaian yang diamanatkan oleh Undang-Undang tersebut tidak hanya tertuju pada peserta didik saja, melainkan juga pada lembaga, dan program pendidikan pada jalur formal dan nonformal untuk semua jenjang, satuan, dan jenis pendidikan. Masyarakat juga diberikan wewenang untuk melakukan evaluasi dengan membentuk suatu lembaga yang mandiri, yang dilakukan secara berkala, menyeluruh, transparan, dan sistemik untuk menilai pencapaian standar nasional pendidikan.

\section{DAFTAR RUJUKAN}

Arifin, Zainal. 2010. Evaluasi Pembelajaran: Prinsip, Teknik, Prosedur. Cetakan ke-2. Bandung: Remaja Rosda Karya

Permendikbud No. 66 tahun 2013

Tilaar, H.A.R. 2006. Standarisasi Pendidikan Nasional; Suatu Tinjauan Kritis. Jakarta: Rineka Cipta

Muslich, Masnur, KTSP Pembelajaran Berbasis Kompetensi dan Kontektual, Panduan Bagi Guru, Kepala Sekolah, dan Pengawas Sekolah, Jakarta: Bumi Aksara, 2007.

Sunardi dan Selly Rahmawati, Penilaian dalam Kurikulum 2013: Membantu Guru dan Calon Guru Mengetahui Langkah-langkah Penilaian Pembelajaran, Jogjakarta: Andi, 2013.

Kunandar, Penilaian Autentik: Penilaian Hasil Belajar Peserta Didik Berdasarkan Kurikulum 2013, Jakarta: Raja Grafindo Persada, 2013.

Kementrian Pendidikan dan Kebudayaan, Panduan Teknis Penilaian dan Pengisian Rapot di SD, Jakarta: Direktorat Jenderal Pendidikan Dasar, 2014.

Ahmadi, Lif Khoiru dan Sofan Amri, Pengembangan dan Model Pembelajaran Tematik Integratif, Jakarta: Prestasi Pustakaraya, 2014.

Muslich, Masnur, KTSP Pembelajaran Berbasis Kompetensi dan Kontektual, Panduan Bagi Guru, Kepala Sekolah, dan Pengawas Sekolah, Jakarta: Bumi Aksara, 2007.

Kurinasih, Imas dan Berlin Sani, Sukses Mengimplemantasikan Kurikulum 2013: Memahami Berbagai Aspek dalam Kurikulum 2013, Jakarta: Kata Pena, 2014.

Mulyasa, E, Pengembangan dan Implementasi Kurikulum 2013, Bandung: Remaja Rosdakarya, 2013.

Kementerian Pendidikan dan Kebudayaan, Dokumen Kurikulum 2013, Jakarta: Kemendikbud, 2013 
Trianto, Desain Pengembangan Pembelajaran Tematik: Bagi Anak Usia Dini TK/RA dan Anak Usia Awal SD/MI, Jakarta: Kencana, 2011.

Hidayat, Sholeh, Pengembangan Kurikulum Baru, Bandung: Remaja Rosdakarya, 2013. Kunandar, Op. Cit, hlm. 259-260.

Prastowo, Andi, Pengembagan Bahan Ajar Tematik: Panduan Lengkap Aplikatif, Jogjakarta: Anggota Ikapi, 2013.

Majid, Abdul, dan Dian Andayani Pendidikan Agama Islam Berbasis Kompetensi: Konsep dan Implementasi Kurikulum 2014, Bandung: Remaja Rosdakarya, 2005.

Hajar, Ibnu, Panduan lengkap Kurikulum Tematik Untuk SD/MI, Jogjakarta: Anggota Ikapi, 2013. 